DOI https://doi.org/10.30525/978-9934-588-81-5-2.6

\title{
НОВІ ВИКЛИКИ ХХІ СТОЛІТТЯ: COVID-19
}

\author{
Віцюк А. А. \\ кандидат педагогічних наук, доцент, \\ доиент кафедри соиіально-гуманітарних дисциплін \\ ПВНЗ «Міжнародна академія екології та медицини» \\ м. Київ, Украӥна
}

Сьогодення принесло людству загалом та Україні зокрема багато нових відкритттів, динаходів, а також випробувань. 3-поміж них варто виокремити таку хворобу, як COVID-19. Саме тому актуальним $\epsilon$ дослідження іiї особливостей, профілактики, симптомів та можливих способів захисту.

Перш за все, варто зазначити, що це захворювання, спричинене новим коронавірусом, вперше було виявлене у Вухані, Китай, та отримало назву коронавірусного захворювання 2019 (COVID-19). «CO» означає corona (корона), «VI» - virus (вірус) та «D» disease (захворювання). Раніше це захворювання називали «новим коронавірусом 2019 року» або 2019-nCoV. COVID-19 - це новий вірус, пов'язаний із тим же сімейством вірусів, що і гостра респіраторна вірусна інфекція (ГРВІ) та деякі типи звичайної застуди [1].

Вірус передається від людини до людини краплинним та контактним шляхами. Тобто через дрібні часточки, які виділяються з носа або рота хворого на COVID-19 під час кашлю або чхання. Ці краплі розповсюджуються на відстань близько метру від хворого і можуть потрапляти на слизові оболонки очей, носа та рота іншої людини, яка знаходиться поруч. Також краплі, що містять вірус забруднюють предмети і поверхні. Інші люди можуть інфікуватися через дотик до таких предметів або поверхонь, а потім - до очей, носа чи рота.

Вірус не передається повітряним шляхом. Це означає, що він не здатен переноситись потоками повітря на великі відстані від хворої людини.

Вірус може переміщуватись на відстань понад метр у часточках аерозолю, але такий аерозоль утворюється лише під час виконання специфічних медичних процедур. Наприклад, інтубація трахеї [2].

Багато людей, які заражаються, відчувають легкі симптоми і одужують, але деякі люди можуть переносити хворобу досить тяжко. Симптоми включають поєднання:

- Лихоманка 
- Кашель

- Утруднене дихання

- Біль у м'язах

- Втома

Загальні рекомендації щодо профілактики COVID-19 такі:

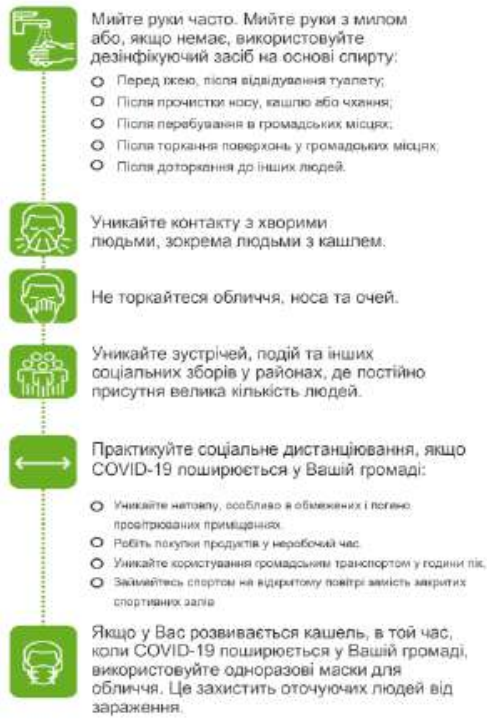

У наш час необхідно бути не лише інформаційно освіденою особистійстю, але й орієнтуватися у новітніх термінах та поняттях. Тому варто варто розмежовувати такі поняття:

Коронавірус - це родина вірусів, до якої належить вірус SARS-CoV-2, з яким ми маємо справу сьогодні. До цієї ж родини належить також коронавірус близькосхідного респіраторного синдрому MERS-CoV, який вперше діагностували у 2012 році у Саудівській Aравії, і коронавірус тяжкого гострого респіраторного синдрому SARS-CoV, який спричинив спалах епідемії у 2003 році.

SARS-CoV-2 - це наукова назва вірусу, який викликає хворобу COVID-19. SARS-CoV-2 - це скорочення терміну «коронавірус тяжкого гострого респіраторного синдрому-2.

Заходи безпеки

Фізичне або соціальне дистанціювання - це заходи обмеження контакту між людьми поза межами їхніх домівок. Такі заходи радять, 
щоб запобігти зараженню людей, зокрема від тих, хто ще навіть не проявляє симптомів. Всесвітня організація охорони здоров'я (ВОО3) рекомендує триматися на відстані не менше двох метрів один від одного.

ВООЗ почала використовувати термін «фізичне дистанціювання», який є точнішим і не означає, що суспільство «повинно розділитися», як це може здатися у випадку раніше вживаного терміну «соціальне дистанціювання».

Самоізоляція - це складніша форма фізичного дистанціювання $\mathrm{i}$ зазвичай стосується людей, які ізолюються самостійно, бо належать до групи підвищеного ризику, яка вразлива до інфекції.

Це також може стосуватися людей, які ізолюють себе від решти населення, бо вони, можливо, контактували з людьми, які отримали позитивні результати тесту. А отже, їм потрібно чекати 14 днів, щоб переконатися, що вони самі не були заражені.

«Локдаун» (Lockdown) - цей термін, який не має прямого українського відповідника, часто використовується в англомовних джерелах на позначення обов'язкового розпорядження влади про те, щоб жителі певного міста, регіону або іншої частини території країни залишалися у своїх домівках, щоб уникнути розповсюдження інфекції.

У Сполучених Штатах цей наказ також називають «сховайся, де ти $\epsilon »$ (shelter-in-place) або «залишайся в себе вдома» (stay-in-your-home).

Карантин - це найсерйозніший стан ізоляції, впроваджений владою. Зазвичай такі суворі правила застосовують, щоб відокремити інфікованих пацієнтів від решти населення. Карантин може також стосуватися ізоляції людей із високим ризиком зараження задля безпеки та перешкоди розповсюдженню хвороби.

Варто зазначити, що «локдаун» та «карантин» у багатьох країнах використовуються як синоніми. Щоб уникнути неоднозначності, слід звертати увагу, які саме заходи ізоляції застосовує влада.

Термін «друга хвиля» стосується можливості того, що коли країни припинять карантин, а люди повернуться в офіси, школи та інші громадські місця - це може викликати новий спалах інфекції, викликаної надзвичайно заразним вірусом COVID-19. Експерти стверджують, що лише завдяки створеній вакцині буде можливо повністю безпечно зняти всі карантинні обмеження, яких зазнала половина людства. Проте, уряди країн дедалі частіше послаблюють карантин через його руйнівний вплив на світову економіку.

ПЛР-тести (тест полімеразної ланцюгової реакції) - найточніший спосіб визначити, чи заразилася людина вірусом COVID-19, навіть якщо у неї немає симптомів. Тест передбачає використання тампона для горла, яким у людини беруть зразок мокротиння для прове- 
дення лабораторного аналізу, щоб виявити унікальний генетичний код вірусу COVID-19. Люди з позитивним тестом на вірус можуть бути поміщені в карантин, щоб запобігти поширенню вірусу серед інших.

«Скринінг» - це загальний термін, який може означати використання будь-якої кількості різних методів, щоб визначити, чи зазнала людина впливу коронавірусу або чи має симптоми захворювання.

У деяких країнах методи скринінгу передбачають масове вимірювання температури, прохання до людей заповнити анкети або проведення телефонних опитувань. Для ясності, слід завжди намагатися уточнити, який саме метод використовується під час «скринінгу» на коронавірус.

Тестування - це специфічний термін, який зазвичай стосується перевірки наявності інфекції в людини за допомогою лабораторних аналітичних методів.

Однак майте на увазі, що деякі країни та 3МІ можуть використовувати цей термін більш загально, щоб описати будь-які методи «скринінгу». Щоб уникнути неоднозначності, варто вказувати, які методи використовуються, коли йдеться про «тестування» на коронавірус [4].

Отже, COVID-19 - це складне захворювання, яке потребує подальшого ретельного вивчення та аналізу, а також свідомого ставлення громадян до заходів профілактики та зменшення ризику поширення.

\section{Література:}

1. Що таке «новий» коронавірус? [Електронний ресурс]. - Режим доступу: https://www.unicef.org/ukraine/coronavirus

2. Що варто знати про COVID-19 [Електронний ресурс]. - Режим доступу: https://phc.org.ua/news/scho-varto-znati-pro-covid-19

3. Коронавірус: Загальна інформація [Електронний ресурс]. - / Режим доступу: http://www.pfizermed.com.ua/public/covid19-first

4. Словник термінів, які потрібно знати під час пандемії COVID-19 [Електронний ресурс]. - Режим доступу: https://www.radiosvoboda.org/ a/koronavirus-terminy-slovnyk/30520097.html 